Article

\title{
A Systems Engineering Approach to Performance-Based Maintenance Services Design
}

\author{
Maria Holgado (iD \\ Department of Management, University of Sussex Business School, Brighton BN1 9SL, UK; \\ m.holgado@sussex.ac.uk; Tel.: +44-1273-877166
}

Received: 23 December 2018; Accepted: 21 January 2019; Published: 23 January 2019

check for updates

\begin{abstract}
Traditionally, industrial services have been mainly transaction-based, i.e., the equipment user pays the service provider for getting a job done or providing assistance and support for equipment operations. Recently, a trend has emerged of increasing the relational perspective of these services, which are becoming more oriented towards customer value and service performance levels. Among these emergent industrial services, performance-based services represent an opportunity for equipment manufacturers to transform their service offerings towards more relational and customer-oriented services. The purpose of this work is to study the design of a generic performance-based maintenance service under a novel perspective given by systems engineering. This paper is intended to serve as a starting point to fully understand this type of services and to develop a method that can support equipment manufacturers who wish to advance their service offerings.
\end{abstract}

Keywords: industrial services; performance-based services; outcome-based services; maintenance services; systems engineering; IDEF0

\section{Introduction}

The extension of a product lifetime is one of the key strategies to achieve sustainability in the manufacturing industry [1]. From the viewpoint of manufacturing facilities and equipment, this means considering the extension of a piece of equipment's life cycle-regarding its life expectancy and potential second and consecutive lifecycles-as a crucial element to reach more sustainable operations, as well as a business opportunity for equipment providers. More attention is given to the use phase and the end of equipment working life, including maintenance and remanufacturing as levers [2]. For example, new business concepts related to the provision of better customer support and advanced services have arisen in recent years that include the responsibility of equipment maintenance [3,4]. Thus, maintenance has acquired a more central role in industrial services provision. New business concepts have influenced the evolution of industrial services, from being just an add-on for equipment acquisition to becoming part of integrated solutions [5]. This trend has been further emphasized due to the increased focus on technological innovations in the servitisation of manufacturing. There is great opportunity for leveraging on emerging technologies to enhance service design and innovation [6,7], e.g., Industry 4.0 [8,9], cyber physical systems [10] and e-maintenance technologies [11]. These technologies bring promising additional features to industrial service provision.

Equipment-based services include a wide range of possible types of services regarding their coverage of equipment life cycle phases, and their scope, i.e., the range of activities performed/included in the service offering. According to Kumar et al. [12], services delivered by a maintenance provider can include: assistance in defining product specification; assistance during the installation and commissioning phase of a product/system; assistance in defining the operational strategy; field 
service; remote diagnostics; on site diagnostics and repair; online and phone help desk; optimization of logistic support; and assistance in product end-of-life (EOL) management. This non-exhaustive list of maintenance-related services is presented to illustrate with examples that maintenance services are delivered along the whole equipment life cycle, considering services in the beginning-of-life (BOL) phase such as 'assistance in defining product specification', services in the middle-of-life (MOL) phase such as 'remote diagnostics' and services in the EOL phase such as 'assistance in EOL management'. However, these maintenance services represent a transactional perspective. A more relational perspective of maintenance services brings up other types of industrial services which are characterized by a measure of equipment performance levels, such as performance-based contracting (PBC). PBC approaches are reshaping the conventional after-sales service model [13]. Initiated in the aerospace and defense industry, they have now been introduced into other sectors such as the transport, automotive, machinery and equipment manufacturing industries [14-16]. This type of maintenance service enhances the in-service phase and requires a better understanding of equipment usage conditions by the service provider [17]. As Goldstein et al. [18] mention, even simple services involve a large number of decisions to bring the new service from the idea stage through design phases to a deliverable service. This brings challenges to service design and raises the need for decision support methods and tools that help equipment manufacturers and service providers.

The purpose of this work is to study the design of a generic, performance-based maintenance service (PBMS) under the perspective given by systems engineering (SE). According to Davies [19], a systems approach involves a careful, phased process. To this end, the steps suggested by the Generalised Enterprise Reference Architecture and Methodology (GERAM) [20] for the definition of a systems life cycle are applied in order to obtain the best possible design of the system under study, i.e., the PBMS system. The main contribution of this work is to demonstrate how SE can be an effective approach to design industrial services. Establishing a systematic approach for industrial service design supports the advancement of this relevant research area for service science, and contributes to the development of tools and methods for service design, organizational design and organizational transformation, which are key priority areas for service research [21,22].

\section{Background on Maintenance Services}

Early references to maintenance services as a subject of study take the perspective of the company acquiring the services as part of an outsourcing strategy. Contracting out maintenance activities responded to a desired to focus on core activities and contracts were signed with several types of companies: the equipment manufacturer, a service provider that is dependent on the equipment manufacturer or an independent service provider [12,23]. This was especially interesting in cases of high equipment complexity and uniqueness [24,25]. Benefits and value of the service were initially investigated from the perspective of the company contracting-out maintenance tasks, i.e., the equipment user [26]; whereas more recent research has also included the analysis of value for the service provider [27-29]. Traditionally, contracting-out maintenance activities have been done through several types of contracts, ranging from those in which the customer indicates what maintenance activities or interventions to perform in the equipment to lease contracts that last for a specific period of time [30]. Among these types, performance contracts are those based on the contractors' guarantee of a certain level of performance that may include, for example, equipment availability, failure rates, response time or time to restoration. A key element in this type of contract is the relationship between both parties involved [16,31].

PBC approaches, which are gradually gaining importance in different industrial sectors, have experienced increased attention in academic research. However, there is still no consistent terminology for this type of service approach [32]. PBC is also referred to as outcome-based contracting (OBC) [33,34], functional product [35,36], Total Care Products [37], full service offerings [38] and performance contracting [39]. Related generic service-based business concepts, including performance-based 
solutions, are also referred to as integrated solutions, functional sales, servicizing, product service systems (PSS) and product-life extension services [3,40].

A common characteristic of all of these terms is that the customer purchases a specific performance, result, and/or output, and the service provider, which is frequently the equipment manufacturer, offers all the support and actions necessary to achieve the target outcome [37,40]. Therefore, the responsibility on ensuring that the correct maintenance activities and intervention are performed to achieve the desired outcome is transferred to the service providers through the PBC [17]. For example, service providers can select the mix of preventive and corrective actions that retain adequate control of the service demand and optimize the service operations [41]. This means more capacity to plan and control the necessary resources for maintenance actions for the service provider. Industrial customers gain different types of value from $\mathrm{PBC}$ approaches [38]. The expected benefits of performance-based services include a reduced cost of ownership for the equipment as well as better equipment reliability and environmental performance [42-44].

This type of service is typically adequate for capital-intensive, complex goods with long life time expectation, requiring considerable efforts to maintain and where the consequences of its breakdown are severe and disruptive [40]. Industrial customers primarily appreciate two aspects related to this type of contract: the reputation of the service provider and the level of detail on the maintenance activities included in the service agreement [38]. This indicates that the trust and expertise of the provider are key in PBC, as well as information sharing. The service agreement would describe the main content of the service offering, the responsibilities of each party and the expected performance levels to be achieved during the service delivery [5]. Payment methods in PBC reflect the high variety of performance measures required by different customers and the differences in business contexts in which these type of services emerge. The variety of payment methods is also possible due to the measurement of the equipment performance levels, which makes it possible to connect the payment to the desired levels of performance. Specifically, payments can be made via a budget provided to the service provider or based on the actual results achieved. Hypko et al. [14] define two approaches within the actual results payment method in PBCs: pay-on-availability or based production outcomes, e.g., pay-per-unit or pay-per-use. These latter approaches support the shift towards more relational services that focus on what is valuable for the customer [45].

Although the benefits seem to be multifold, there are concerns about the extent to which these type of services are actually used in practice [32,40]. This calls for further research on this particular type of industrial maintenance services and effective methods and techniques to develop more appealing and value-added PBMSs that leverage fully on their envisaged benefits.

\section{Materials and Methods}

The systems thinking approach seems adequate for industrial services design for several reasons. It can address the complexity of technical service systems in a systematic manner and, additionally, its application to service system design has been linked with enhanced environmental and social benefits while indirectly contributing to economic benefits [46]. The main aspects of systems thinking are related to gaining a bigger picture and appreciating other people's perspectives [47]. Thus, getting a higher level of abstraction that includes relationships between things and incorporating several stakeholders' viewpoints are intended to be useful means to obtain a holistic view of the systems of interest, which are defined as "sets of activities which could be described as being organized around a single/particular purpose" [48]. These elements could be hardware, software, equipment, facilities, personnel, processes, and procedures [49]. The value added by the system as a whole, beyond that contributed independently by the parts, is primarily created by the relationship among the parts, i.e., how they are interconnected [50]. This seems adequate to study more relational services such as performance-based service types.

One commonly-used approach to systems thinking is based on a quantitative modeling approach to systematic analysis. This "hard systems" approach reflects a functionalist view that focuses on 
system designs and provides the clarity of analysis that can be applied by using an unambiguous expert definition of objectives and other properties. Therefore, given a set of defined system objectives, a system can be engineered to achieve the objectives [48]. Aligned with this vision, SE is considered as an interdisciplinary approach to enable the development of successful complex systems [51]. It is defined as the art (technical leadership) and science (system management) of developing an operable system that meets the requirements within imposed constraints while keeping a holistic and integrative approach [52]. It seems an appropriate approach for PBC analysis [53].

An important perspective brought up by SE is the system life cycle concept to enable the development of a comprehensive solution "from requirements determination through operations and system retirement by assuring that domain experts are properly involved, that all advantageous opportunities are pursued, and that all significant risks are identified and mitigated" [54]. A system life cycle is described as an abstract functional model that represents the conceptualization of a need for the system, its realization, utilization, evolution and disposal [55]. This concept, fundamental to SE, can be applied to different types of systems to improve their design or uncover hidden aspects of the system life cycle. For example, it has been applied by following the standard ISO/IEC/IEEE 15288 to assess the impact and potential of additive manufacturing [56]. Life Cycle Processes contribute directly to the creation of products, systems, or services, reflecting the lean view of an overall lifecycle within which functions serve, as opposed to the more traditional paradigms that allow each function to suboptimise around its own operations [57]. By defining the system life cycle, a framework to meet the stakeholders' needs in an orderly and efficient manner is created [54]. SE standards include specific processes to deal with the identification of stakeholders' needs and requirements [55].

System life cycle stages indicate the major periods, decision gates and milestones associated with the system life cycle [55]. The life cycle stages proposed by GERAM are defined as [20]:

- Identification stage, where the contents of the system in terms of its boundaries and relation to its internal and external environment are determined;

- Concept stage, that considers the conceptual development of the system in terms of its mission, vision, values, strategies, objectives, operational concepts, policies, business plans and so forth;

- Requirement stage, where the operational requirements, its relevant processes and its functional, behavioral, informational and capability are described;

- Design stage, that supports the specification of the system considering all its components, their task description and resources needs;

- Implementation and build stage, where the activities necessary to build the system are carried out;

- Operation and change/re-engineering, where the system operation is monitored, controlled and evaluated and operation-related resources are managed to assure that the system can fulfil its mission;

- End of Life, that considers the necessary activities to recycle or disposal the system and its components at the end of its useful life.

Though several systems life cycle stages have been proposed in the literature, the main phases remain similar in each proposal. For example, the proposal from the International Council on Systems Engineering (INCOSE) [54] defines the following stages: concept, development, production, utilization, support, retirement. For this work, the stages described above and proposed by GERAM [20] have been preferred for the application of SE to PBMSs as the specification of the change/re-engineering activities would bring a necessary feedback loop during later application stages. Additionally, the last stage proposed by GERAM [20] also provides a wider scope for value recovery activities at the end of life of the system. Other standards mainly refer to retirement plans and procedures for the system [58]. The inclusion of value recovery activities, e.g., reuse, remanufacturing or recycling, is more aligned to the circular economy perspective of industrial equipment [59].

Among all life cycle stages, this work focuses on the first four stages which are taken as a starting point to assess the usefulness of the SE application to PBMS systems design. Further stages will be 
considered in later extensions of this work. The three initial stages have been performed by using a sound modelling technique, the Integration Definition for Function Modeling (IDEF0). This technique makes it possible to include contextual and requirements information without needing an in-depth description, which was important for this illustrative application. IDEF0 has been previously used successfully to define and describe the links between elements and stakeholders in other types of industrial services [60]. The fourth life cycle stage used a graphical language that is used for specifying, visualizing, constructing and documenting systems, the Unified Modelling Language (UML). UML enables the representation of different elements with enough level of detail to support the design of technical services during the specification phase [61]. These techniques have been selected due to their background in engineering systems design and desired characteristics. Other techniques used in service design are rooted on marketing and management domains, e.g., based on a service-dominant logic [62]. Examples of specific techniques used in different stages of service design are service blueprints or customer journeys [63,64], TRIZ (Theory of Inventive Problem Solving) and QFD (Quality Function Deployment) $[65,66]$. Several reviews of approaches, methods and tools can be found in the literature [67-69]. The selected techniques to be applied in this study are briefly presented herein.

IDEF0 represents the functions, activities or processes defining a system in a structured manner. It consists of a series of hierarchical diagrams that progressively decompose the system under study. The following set of rules are used for the decomposition of the system [70]: (i) a process is modelled as a sequence of activities that form a diagram; (ii) in a given diagram (parent diagram), any activity can be further decomposed; (ii) all sub-activities of the one decomposed create another diagram (child diagram) and so on. An IDEF0 representation model includes two types of components: functions and data or objects. The functions are represented by boxes in the diagrams, while the data or objects are represented by arrows. The arrows in an IDEF0 diagram depict four types of data or objects [70]: (1) Input arrows refer to data or objects that are transformed by the function into outputs; (2) Output arrows are used for data or objects produced by a function; (3) Control arrows represent the conditions required to produce the outputs in a correct manner; and (4) Mechanism arrows represent the means needed to perform a function.

The use of IDEF0 to represent system processes permits both an almost indefinite decomposition of its processes/activities in connected diagrams through a hierarchical approach, and the possibility to highlight different types of processes/activities by coloring the boxes as proposed by Macchi et al. [71]. This brings numerous possibilities to the description of PBMS systems, as it could serve, for example, to differentiate activities performed by the different parties during the service provision.

UML as a graphical language has proven to be successful in the modelling of many large and complex systems [72]. It consists of thirteen kinds of diagrams that can represent either static or dynamic aspects of the system. The diagram used here is the known as "class diagram", and supports the description of key information related to different objects of the system, as well as the relations between them. The class diagram defines the name, attributes and methods related to each type of object of the system. It also indicates its role within the system, and a cardinal number identifies the type of relation between connected objects.

\section{Results}

\subsection{Life Cycle Stage 1: System Identification}

As mentioned before, a generic PBMS is studied in this work. The PBMS features described are inspired on participatory observations of various industrial maintenance services provided by a multinational company in the electronics and electric goods sector that is both an equipment manufacturer and an independent service provider. The observations, which lasted for two years, relate to both roles of this company: servicing its own goods and servicing other manufacturers' goods. The identification of the system describes its content and defines its boundaries and environment. This also includes the identification of stakeholders relevant to the system under study. The boundaries 
of the system are described by a set of assumptions taken to simplify the study and by a high level description of system's purpose, inputs/outputs and viewpoints to be considered in its design. The set of assumptions defined for the PBMS system are the following:

1. The actors involved are two; the service provider and the customer, i.e., the user of the manufactured good. This approach is taken for simplicity; in practice, a PBMS system could potentially involve several actors forming a maintenance service network [73,74].

2. The PBMS is provided for only one piece of equipment (i.e., the manufactured good) installed in the industrial site of the customer. This is another simplification, as performance-based services are often delivered to a set of equipment within an industrial plant.

3. Although performance-based services can include a more complex definition of various performance targets, the performance objective for the PBMS under study is defined based on one main measure: the equipment availability. This is aligned with the approach of Hypko et al. [14], i.e., pay-on-availability.

A customer-focused purpose for the PBMS system is defined as 'to provide the industrial user with the agreed service level'. This service level refers to the target performance objective based on an agreed level of equipment availability to be achieved during the service delivery. Additionally, the study considers the viewpoints of several stakeholders with responsibilities for asset management, production and maintenance management, supply and logistics management, and service management. The latter refers to the management team of the service provider. Figure 1 presents the highest level diagram of the IDEF0 representation for the PBMS system. This diagram describes the context of the PBMS system, including its inputs (I), outputs (O), controls (C) and mechanisms named as resources (R), represented with arrows. The purpose of the system is defined in terms of a functional objective for the PBMS system, as 'to perform the right maintenance activities at the right time and in the right way'. Thus, this function needs to be performed in order to achieve the customer-focused system's purpose.

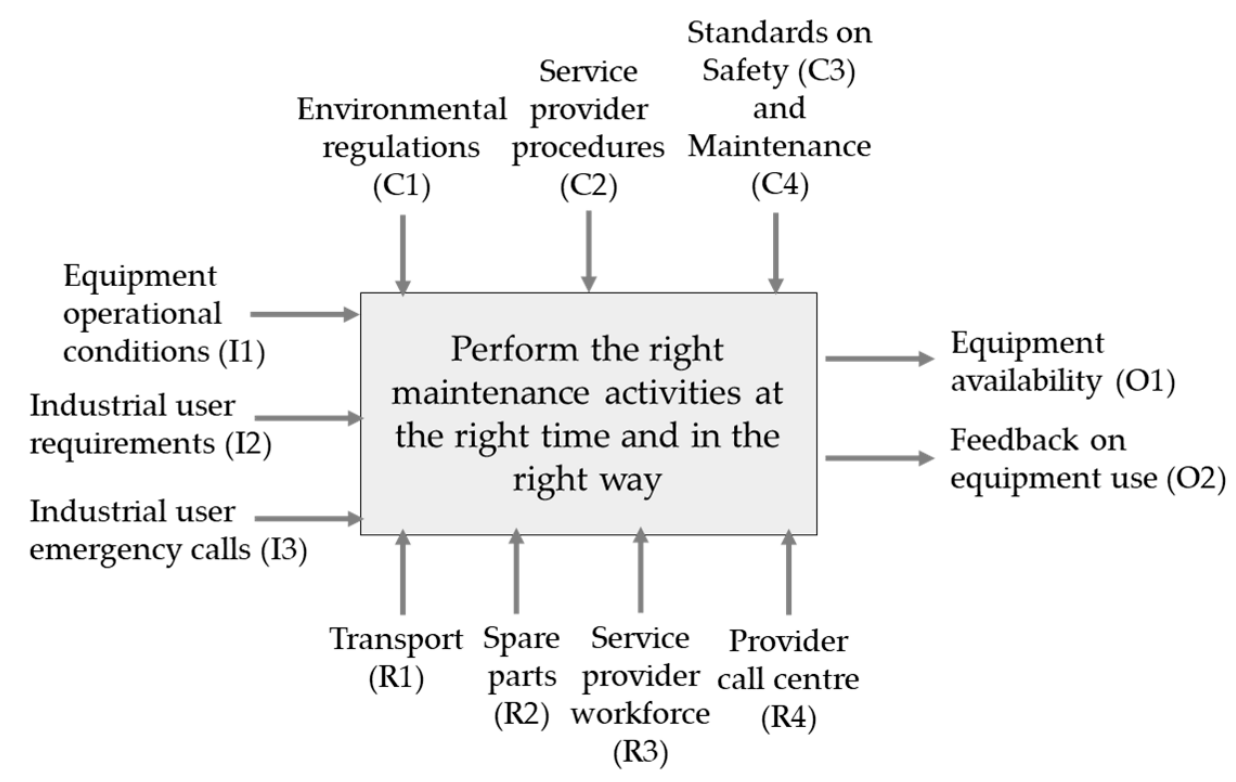

Figure 1. Integration Definition for Function Modeling (IDEF0) high-level diagram for performancebased maintenance service (PBMS).

The inputs for the PBMS system include equipment operational conditions (I1) and industrial user requirements (I2) which come from a deeper knowledge on the customer needs and requirements related to the equipment performance and context. The outcomes of the PBMS system are mainly twofold: the expected and agreed equipment availability level (O1) and feedback on the equipment use 
(O2) that can be of great value for the service provider and the equipment manufacturer. The resources needed have been identified as transport means (R1), spare parts (R2), service provider workforce (R3) and call center of the service provider (R4). The controls for the PBMS system operation are environmental regulations (C1), service provider internal procedures (C2), safety standards (C3) and maintenance standards (C4). The latter includes standards such as EN 17007 [75] and EN 15341 [76]. The EN 17007 [75] provides a generic description of maintenance processes, their characteristics, necessary inputs, expected outputs and the interactions between different processes. The EN 15341 [76] provides a comprehensive list of maintenance measures and key performance indicators. These standards will be fundamental for the service offering definition and the planning of maintenance actions and interventions during the service delivery.

\subsection{Life Cycle Stage 2: System Concept}

The high-level function identified in the previous step needs to be decomposed into several lower level tasks. An important characteristic of PBMSs is that the service provider is in charge of the selection of the most adequate maintenance strategy and the definition and execution of maintenance plans. It is crucial for the service provider to perform these activities efficiently. In order to identify the tasks to deliver the high-level function, the understanding of new service development processes and the steps suggested in previous works have been essential at this PBMS life cycle stage. Johnson et al. [77] suggested the NSD (New Service Development) process cycle, which represents a progression of planning, analysis, and execution activities. Aurich et al. [78] propose the following steps for service development: service planning, service conception, service preparation and service realization. Yang et al. [79] considers service requirement, service deployment, service processing and service retirement as key aspect within a service process model. Based on these proposals, the second-level tasks are defined integrating some of the above approaches together with the maintenance management tasks needed. These tasks are described as:

- The requirement analysis concerns the formulation of customer needs to be integrated into the service offering. A specific focus is given to identify the functional requirements of the equipment as they are considered the basis for designing maintenance-related services [80]. This analysis would also take into consideration different viewpoints in relation to the system under study, i.e., the viewpoints of relevant stakeholders and their needs and requirements in relation to the system. A set of tasks to perform this identification and analysis of stakeholders specifications have been proposed in the ISO/IEC/IEEE 15288 standard [55].

- The service offering definition consists of the identification of different service packages that could be proposed to the equipment user and the development of the service agreement between both parties. This is a crucial part of the negotiation process as many difficulties may arise while performing this task. Difficulties in this stage may include the identification of risks and uncertainties and definition of responsibilities to tackle them, and the specification of boundaries and roles of different actors [81-83].

- The maintenance planning activities are related to the design of the preventive maintenance plan adapted to the particular equipment conditions and operational requirements, as well as the necessary resources to perform the maintenance activities planned.

- The maintenance scheduling activities would program in a short-term perspective the necessary maintenance activities and resources according to the maintenance plan.

- The maintenance execution is a personnel intensive task. Special attention is paid to the staff delivering the service as it could vary the results of the service [84].

- The service monitoring and evaluation task consists of the assessment of the actual outputs of the service provision to understand whether the requirements have been fulfilled as stated in the service agreement. An example of possible measure of maintenance planning and scheduling effectiveness is the percentage of compliance with the maintenance plan [85]. 


\subsection{Life Cycle Stage 3: System Requirements}

The requirements of the PBMS system have been identified by realizing a functional analysis to decompose the high level function and to characterize in further details its second level tasks. Thus, for each task identified as part of the system concept, a functional study based on IDEF0 was performed. This has permitted us to define intermediary inputs and outputs for the different tasks that had not been identified during the identification of system boundaries done in the first stage. Moreover, the resource type 'service provider workforce' is divided into two types: service development personnel (R3-S), that designs and agrees the service offering with customer, and maintenance execution personnel (R3-M), that performs the maintenance activities onsite and has knowledge on equipment current conditions. Figure 2 shows the functional analysis of the second-level tasks. It is worth pointing out that the intermediary inputs/outputs have not been represented by a code but by naming them. All other codes shown here are those introduced initially in Figure 1.

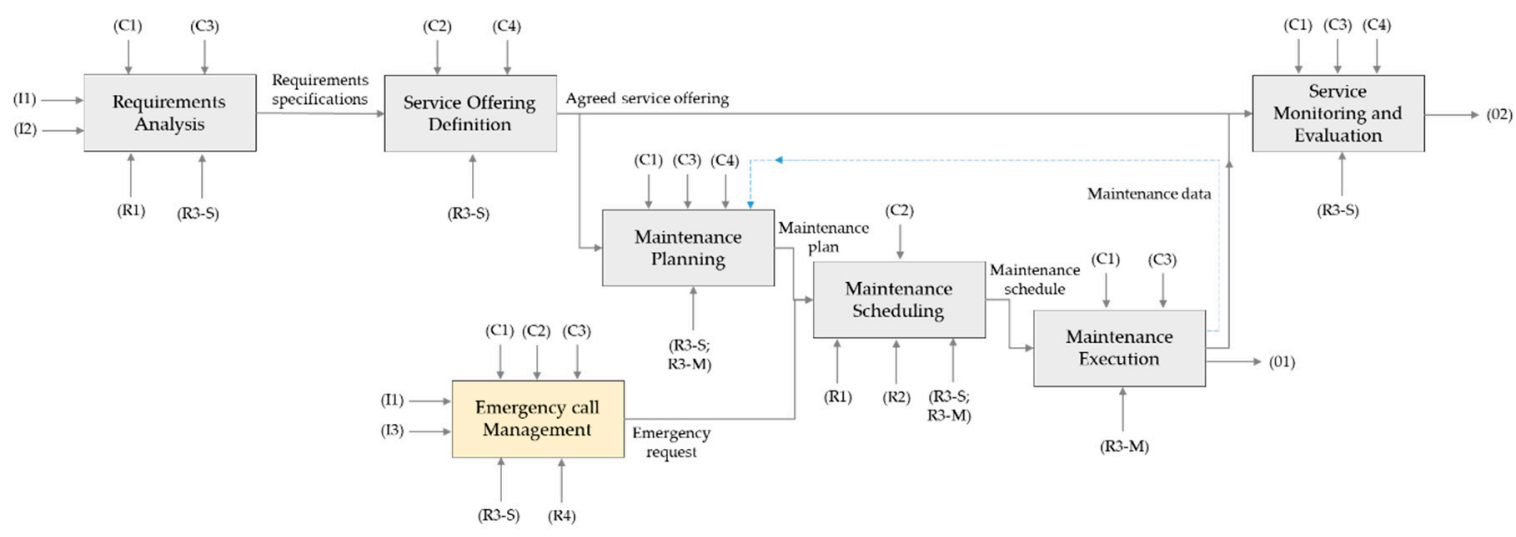

Figure 2. IDEF0 second-level diagram for PBMS.

At this level of analysis, a new task was introduced in Figure 2 with a twofold objective. First, to include the fact that the planned maintenance schedule could be perturbed by emergency actions to be taken in case of incidents within the industrial plant. Second, to illustrate how a task performed by another party could be illustrated in an IDEF0 diagram by changing the color of the box that represents that specific task. In this case, the third party task is named 'emergency call management' and illustrated in yellow in Figure 2.

The intermediary outputs of the different tasks are in some cases necessary inputs for the adequate performance of the following task. These four intermediate outputs are the following:

- The description of requirements specifications resulting from the requirements analysis and informing the service offering definition.

- The accepted service offering, agreed with the equipment user, will be an input for the maintenance planning task, as well as for the service monitoring and evaluation task. The latter is responsible for assessing whether the actual service delivers what was agreed on with the customer.

- The maintenance plan is a necessary input into the scheduling of maintenance activities.

- The maintenance schedule for the PBMS preventive maintenance activities informs the maintenance execution, in terms of time and resources to deliver the activities included in the maintenance plan as programmed to be executed by the maintenance personnel onsite.

- The data generated and collected during the performance of maintenance actions will inform the task that monitors and evaluates how the service is being provided. This information generates a feedback loop going back to the maintenance planning task. The feedback loop is illustrated with a dotted blue arrow in Figure 2. 


\subsection{Life Cycle Stage 4: System Design}

The system structure has been defined by using an UML class diagram, where all objects inside the system are identified by a set of attributes and methods. Five objects were identified at this stage: transport, workforce, spare part, activity, call center. The UML class diagram explains their relations and attributes and is shown in Figure 3.

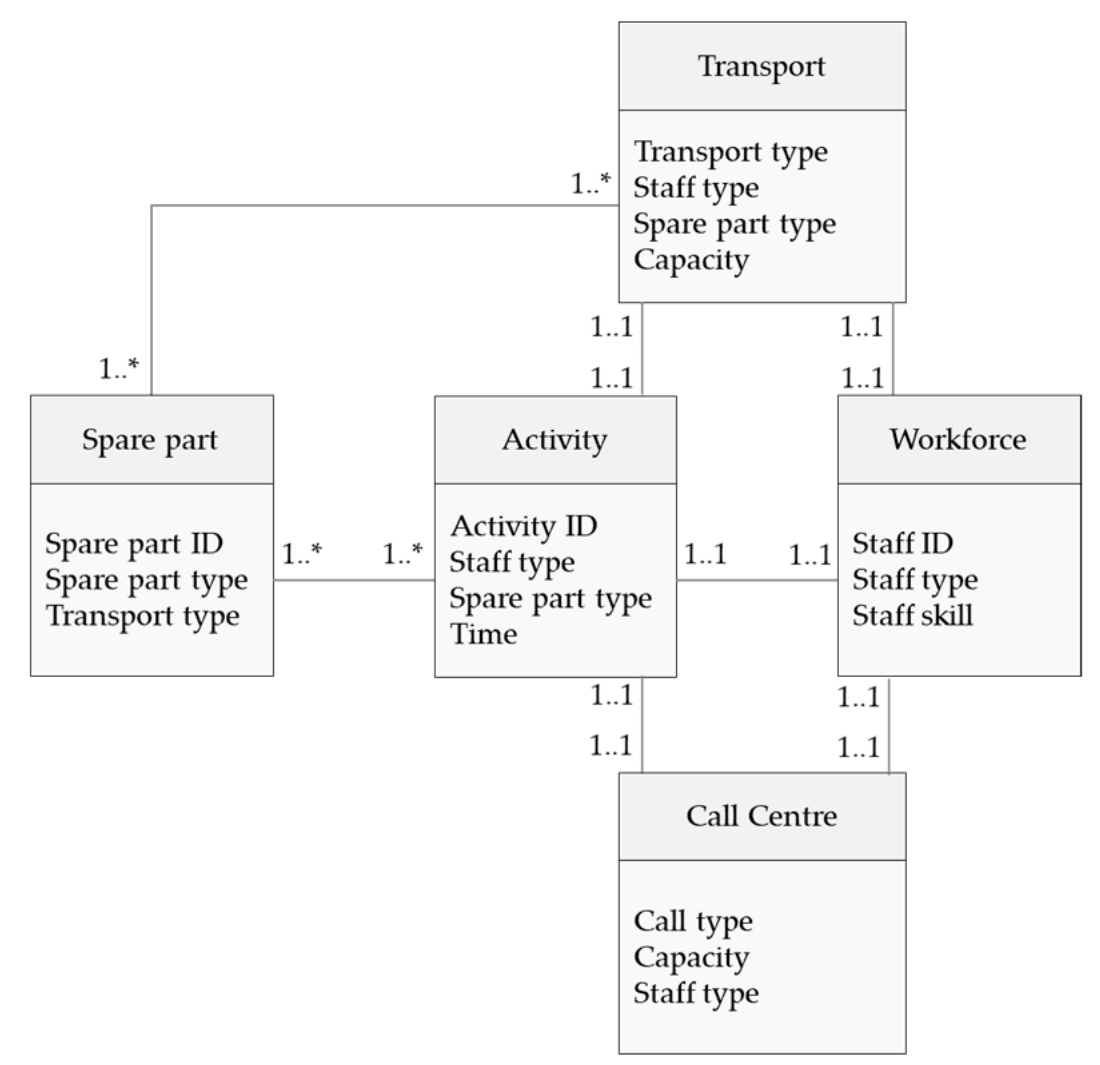

Figure 3. The Unified Modelling Language (UML) Class Diagram for the objects within the PBMS system.

The object 'Transport' considers mobility means to transport the service provider personnel to the site where the service needs to be performed, as well as trucks/delivery vans for spare parts that could be shipped independently.

The object 'Workforce' considers the staff involved in different types of jobs: (i) the service development personnel, which define the PBMS and plan the maintenance activities to be performed; and the maintenance execution personnel, which perform the maintenance activities related to the PBMS on the equipment user site.

The object 'Call center' receives emergency requests from industrial users that may lead to the performance of a corrective maintenance action. As mentioned before, the task managing the equipment user emergency calls is designed to be outsourced to a third party. This is done to provide an example of the integration of third party activities into the service provision and how it could be illustrated in the process mapping.

The object 'Activity' includes all the second-level tasks identified as part of the system requirements and presented in the previous Figure 2.

The object 'Spare part' considers the replacement materials to be used in maintenance actions that needs to be either onsite or delivered on time for the performance of the scheduled maintenance activities. 


\section{Discussion}

Customer support entails all activities which ensure that a product is available for trouble-free use to consumers over its useful life span [86]. In the context of industrial equipment, the consumer is the industrial user of production equipment that is interested in obtaining the required outputs from the equipment but without having worries or responsibilities regarding its maintenance. This is aligned with a more relational approach for industrial services, as discussed in servitisation literature. Therefore, this customer support approach has been integrated into industrial services by enlarging the scope of maintenance services towards a more customer-centric and relational perspective. Performance-based contracts are then understood as support services focusing on equipment performance targets as a main measure for establishing service levels. The required performance level or performance aspect, i.e., reliability, availability, etc., would depend on the particular context of the equipment user, i.e., the customer of the PBMS.

The presented application, inspired by observations of real-life industrial cases, introduced the case of a generic PBMS aiming at providing equipment availability as main service level measure. In cases that consider multiple values of the required performance, or when it is not clear what values the service could be based on, a multi-criteria decision method may be adequate to raise the voice of different stakeholders of the system. For example, the AHP method can support the definition of the relative priorities or weights (reflecting the given importance) assigned to the criteria that characterize a decision [87], and has been used previously to assess the values of other engineering systems, such as e-maintenance platforms [88]. The involvement of key stakeholders in the design process has been pointed out as main element in service design [89]. Suggested stakeholders to be involved in this prioritization from the equipment user side are plant managers, production managers and maintenance managers, while the stakeholders suggested from the service provider side are service development managers and maintenance execution personnel.

This work represents a starting point for a system-level analysis of PBMS design by adopting a structured process based on the SE approach. It contributes to advancing the research field of industrial service design. Further development of this work could set the basis to investigate effective methodologies to support the design of PBMS that improve the provider-customer relationship. This would help addressing the implementation and execution problems of PBC [90]. Novel design methods should target improvements in the dyadic or network relationships to foster this type of advanced services, thus enhancing information sharing and potentially increasing the level of detail on the PBMS system discussed during service agreement stages, which is a key feature for these type of services, according to Stremersch et al. [38].

Further research and extensions of this work will continue the decomposition of the second-level tasks identified within this work, reaching a third or fourth level description of the activities to be performed. This will bring greater insight into the challenges of the design process that maintenance service providers are actually facing.

Another line for further research is the analysis of life cycle stages 5 (implementation and build stage), 6 (operation and change/re-engineering stage) and 7 (end of life stage) for the PBMS system. During the actual implementation stage, the second-level task defined as 'service monitoring and evaluation' will provide insights for the future application of system changes/re-engineering actions to enhance the PBMS outcomes in a continuous improvement approach. This will also take into consideration the evolution of the viewpoints, needs and requirements of the PBMS stakeholders. The life cycle stage 7 concerns the EOL of the manufactured good, in this case, industrial equipment. Further work regarding this stage will evaluate different EOL strategies for the physical resources of the PBMS, e.g., the industrial equipment (whenever the end of the service happens at the end of the equipment useful life), and the strategies and actions needed for an orderly termination of the service contract. Well-planned and relational-focused withdrawals from the industrial service contracted are seldom investigated in the literature, and represent a substantial gap in PBC research [90]. 
Finally, further research will extend the PBMS design towards to integration of technologies in both the service design and the service delivery. Information Technologies, Internet of Things and Industry 4.0 can play a fundamental role in equipment life cycle management and in the servitisation process of manufacturing companies, including the successful implementation and delivery of more advanced services [8,91-93].

Funding: This research received no external funding.

Conflicts of Interest: The author declares no conflict of interest.

\section{References}

1. Seliger, G.; Kim, H.J.; Kernbaum, S.; Zettl, M. Approaches to sustainable manufacturing. Int. J. Sustain. Manuf. 2008, 1, 58-77. [CrossRef]

2. Bashkite, V.; Moseichuk, V.; Karaulova, T. Combination of end-of-life strategies for extension of industrial equipment life cycle. J. Mach. Eng. 2010, 10, 76-88.

3. Lay, G.; Schroeter, M.; Biege, S. Service-based business concepts: A typology for business-to-business markets. Eur. Manag. J. 2009, 27, 442-455. [CrossRef]

4. Reim, W.; Parida, V.; Örtqvist, D. Product-Service Systems (PSS) business models and tactics-a systematic literature review. J. Clean. Prod. 2015, 97, 61-75. [CrossRef]

5. Welp, E.G.; Meier, H.; Sadek, T.; Sadek, K. Modelling approach for the integrated development of industrial product-service systems. In Manufacturing Systems and Technologies for the New Frontier; Springer: London, UK, 2008; pp. 525-530.

6. Patrício, L.; Gustafsson, A.; Fisk, R. Upframing service design and innovation for research impact. J. Serv. Res. 2018, 21, 3-16. [CrossRef]

7. Kroh, J.; Luetjen, H.; Globocnik, D.; Schultz, C. Use and efficacy of information technology in innovation processes: The specific role of servitization. J. Prod. Innov. Manag. 2018, 35, 720-741. [CrossRef]

8. Rymaszewska, A.; Helo, P.; Gunasekaran, A. IoT powered servitization of manufacturing-an exploratory case study. Int. J. Prod. Econ. 2017, 192, 92-105. [CrossRef]

9. Sanchez Egea, A.J.; Lopez de la Calle Marcaide, L.N. Machines, processes, people and data, The keys to the 4.0 revolution. DYNA Ing. E Ind. 2018, 93, 576-577. [CrossRef]

10. Zheng, M.; Song, W.; Ming, X. A Framework for Integrating Industrial Product-Service Systems and Cyber-Physical Systems. In International Conference on Cross-Cultural Design; Springer: Cham, Switzerland, 2016; pp. 628-637.

11. Holgado, M.; Macchi, M.; Fumagalli, L. Value-in-use of e-maintenance in service provision: Survey analysis and future research agenda. IFAC-Pap. 2016, 49, 138-143. [CrossRef]

12. Kumar, R.; Markeset, T.; Kumar, U. Maintenance of machinery: Negotiating service contracts in business-to-business marketing. Int. J. Serv. Ind. Manag. 2004, 15, 400-413. [CrossRef]

13. Jin, T.; Wang, P. Planning performance based contracts considering reliability and uncertain system usage. J. Oper. Res. Soc. 2012, 63, 1467-1478. [CrossRef]

14. Hypko, P.; Tilebein, M.; Gleich, R. Benefits and uncertainties of performance-based contracting in manufacturing industries: An agency theory perspective. J. Serv. Manag. 2010, 21, 460-489. [CrossRef]

15. Ziaee Bigdeli, A.; Bustinza, O.F.; Vendrell-Herrero, F.; Baines, T. Network positioning and risk perception in servitization: Evidence from the UK road transport industry. Int. J. Prod. Res. 2018, 56, 2169-2183. [CrossRef]

16. Visnjic, I.; Jovanovic, M.; Neely, A.; Engwall, M. What brings the value to outcome-based contract providers? Value drivers in outcome business models. Int. J. Prod. Econ. 2017, 192, 169-181. [CrossRef]

17. Datta, P.P.; Roy, R. Cost modelling techniques for availability type service support contracts: A literature review and empirical study. CIRP J. Manuf. Sci. Technol. 2010, 3, 142-157. [CrossRef]

18. Goldstein, S.M.; Johnston, R.; Duffy, J.; Rao, J. The service concept: The missing link in service design research? J. Oper. Manag. 2002, 20, 121-134. [CrossRef]

19. Davies, G.B. Systems approach. Encycl. Inf. Syst. 2003, 4, 351-360.

20. Generalised Enterprise Reference Architecture and Methodology (GERAM). v1.6.3. IFIP-IFAC Task Force on Architectures for Enterprise Integration. 1999. Available online: http:/ /www.ict.griffith.edu.au/ \{\}bernus/ taskforce/geram/versions/geram1-6-3/v1.6.3.html (accessed on 22 January 2019). 
21. Ostrom, A.L.; Bitner, M.J.; Brown, S.W.; Burkhard, K.A.; Goul, M.; Smith-Daniels, V.; Demirkan, H.; Rabinovich, E. Moving forward and making a difference: Research priorities for the science of service. J. Serv. Res. 2010, 13, 4-36. [CrossRef]

22. Baines, T.S.; Lightfoot, H.W.; Benedettini, O.; Kay, J.M. The servitization of manufacturing: A review of literature and reflection on future challenges. J. Manuf. Technol. Manag. 2009, 20, 547-567. [CrossRef]

23. Holgado, M.; Macchi, M.; Fumagalli, L. Maintenance business model: A concept for driving performance improvement. Int. J. Strat. Eng. Asset Manag. 2015, 2, 159-176. [CrossRef]

24. Pascual, R.; Santelices, G.; Liao, H.; Maturana, S. Channel coordination on fixed-term maintenance outsourcing contracts. IIE Trans. 2016, 48, 651-660. [CrossRef]

25. Raddats, C.; Baines, T.; Burton, J.; Story, V.M.; Zolkiewski, J. Motivations for servitization: The impact of product complexity. Int. J. Oper. Prod. Manag. 2016, 36, 572-591. [CrossRef]

26. Cholasuke, C.; Bhardwa, R.; Antony, J. The status of maintenance management in UK manufacturing organisations: Results from a pilot survey. J. Qual. Maint. Eng. 2004, 10, 5-15. [CrossRef]

27. Ali-Marttila, M.; Tynninen, L.; Marttonen-Arola, S.; Kärri, T. Value elements of industrial maintenance: Verifying the views of the customer and the service provider. Int. J. Strat. Eng. Asset Manag. 2015, 2, $136-158$. [CrossRef]

28. Ali-Marttila, M.; Marttonen-Arola, S.; Kärri, T.; Pekkarinen, O.; Saunila, M. Understand what your maintenance service partners value. J. Qual. Maint. Eng. 2017, 23, 144-164. [CrossRef]

29. Toossi, A.; Louise Lockett, H.Z.; Raja, J.; Martinez, V. Assessing the value dimensions of outsourced maintenance services. J. Qual. Maint. Eng. 2013, 19, 348-363. [CrossRef]

30. Martin, H.H. Contracting out maintenance and a plan for future research. J. Qual. Maint. Eng. 1997, 3, 81-90. [CrossRef]

31. Ng, I.C.; Ding, D.X.; Yip, N. Outcome-based contracts as new business model: The role of partnership and value-driven relational assets. Ind. Mark. Manag. 2013, 42, 730-743. [CrossRef]

32. Hypko, P.; Tilebein, M.; Gleich, R. Clarifying the concept of performance-based contracting in manufacturing industries: A research synthesis. J. Serv. Manag. 2010, 21, 625-655. [CrossRef]

33. Hou, J.; Neely, A. Investigating risks of outcome-based service contracts from a provider's perspective. Int. J. Prod. Res. 2018, 56, 2103-2115. [CrossRef]

34. Ng, I.C.; Maull, R.; Yip, N. Outcome-based contracts as a driver for systems thinking and service-dominant logic in service science: Evidence from the defence industry. Eur. Manag. J. 2009, 27, 377-387. [CrossRef]

35. Kumar, R.; Kumar, U. A conceptual framework for the development of a service delivery strategy for industrial systems and products. J. Bus. Ind. Mark. 2004, 19, 310-319. [CrossRef]

36. Markeset, T.; Kumar, U. Product support strategy: Conventional versus functional products. J. Qual. Maint. Eng. 2005, 11, 53-67. [CrossRef]

37. Alonso-Rasgado, T.; Thompson, G.; Elfström, B.O. The design of functional (total care) products. J. Eng. Des. 2004, 15, 515-540. [CrossRef]

38. Stremersch, S.; Wuyts, S.; Frambach, R.T. The purchasing of full-service contracts: An exploratory study within the industrial maintenance market. Ind. Mark. Manag. 2001, 30,1-2. [CrossRef]

39. Jin, T.; Tian, Z.; Xie, M. A game-theoretical approach for optimizing maintenance, spares and service capacity in performance contracting. Int. J. Prod. Econ. 2015, 161, 31-43. [CrossRef]

40. Grubic, T.; Jennions, I. Do outcome-based contracts exist? The investigation of power-by-the-hour and similar result-oriented cases. Int. J. Prod. Econ. 2018, 206, 209-219. [CrossRef]

41. Colen, P.J.; Lambrecht, M.R. Cross-training policies in field services. Int. J. Prod. Econ. 2012, 138, 76-88. [CrossRef]

42. Tukker, A. Product services for a resource-efficient and circular economy-a review. J. Clean. Prod. 2015, 97, 76-91. [CrossRef]

43. Tukker, A. Eight types of product-service system: Eight ways to sustainability? Experiences from SusProNet. Bus. Strategy Environ. 2004, 13, 246-260. [CrossRef]

44. Jin, T.; Nalajala, N.; Jimenez, J.A. A multi-criteria approach for performance based maintenance with variable fleet size. In Proceedings of the 9th International Conference on Reliability, Maintainability and Safety (ICRMS), Guiyang, China, 12-15 June 2011; pp. 909-914.

45. Rapaccini, M. Pricing strategies of service offerings in manufacturing companies: A literature review and empirical investigation. Prod. Plan. Control 2015, 26, 1247-1263. [CrossRef] 
46. Jaaron, A.A.; Backhouse, C.J. Fostering sustainable performance in services through systems thinking. Serv. Ind. J. 2018, 1-27. [CrossRef]

47. Chapman, J. System Failure: Why Governments Must Learn to Think Differently; Demos: London, UK, 2004.

48. Reynolds, M.; Holwell, S. Introducing Systems Approaches. In Systems Approaches to Managing Change: A Practical Guide; Springer: London, UK, 2010; pp. 1-23.

49. Aster, R.; Cassingham, R.C. NASA Systems Engineering Handbook; Boston Library Consortium Member Libraries: Boston, MA, USA, 1995.

50. Rechtin, E. Systems Architecting of Organizations: Why Eagles Can't Swim; Routledge: London, UK, 2017.

51. International Council on Systems Engineering (INCOSE). Systems Engineering Handbook: A "What to" Guide for All SE Practitioners; INCOSE: San Diego, CA, USA, 2000.

52. Ryschkewitsch, M.; Schaible, D.; Larson, W. The art and science of systems engineering. In Systems Research Forum; World Scientific Publishing Company: Singapore, 2009; Volume 3, pp. 81-100.

53. Batista, L.; Davis-Poynter, S.; Ng, I.; Maull, R. Servitization through outcome-based contract-A systems perspective from the defence industry. Int. J. Prod. Econ. 2017, 192, 133-143. [CrossRef]

54. International Council on Systems Engineering (INCOSE). Systems Engineering Handbook: A Guide for System Life Cycle Processes and Activities; INCOSE-TP-2003-002-03.1; INCOSE: San Diego, CA, USA, 2007.

55. ISO/IEC/IEEE 15288. Systems and Software Engineering-System Life Cycle Processes; ISO/IEC: Geneva, Switzerland, 2015.

56. Togwe, T.; Tanju, B.; Eveleigh, T.J. Using a systems engineering framework for additive manufacturing. Syst. Eng. 2018, 21, 466-475. [CrossRef]

57. Nightingale, D.J.; Rhodes, D.H. Enterprise systems architecting: Emerging art and science within engineering systems. In Proceedings of the ESD External Symposium, Cambridge, MA, USA, March 2004; pp. 1-13.

58. ISO/IEC/IEEE 15289. Systems and Software Engineering-Content of Life-Cycle Information Items (documentation); ISO/IEC: Geneva, Switzerland, 2017.

59. Lieder, M.; Rashid, A. Towards circular economy implementation: A comprehensive review in context of manufacturing industry. J. Clean. Prod. 2016, 115, 36-51. [CrossRef]

60. Morelli, N. Developing new product service systems (PSS): Methodologies and operational tools. J. Clean. Prod. 2006, 14, 1495-1501. [CrossRef]

61. Aurich, J.C.; Fuchs, C.; Wagenknecht, C. Life cycle oriented design of technical Product-Service Systems. J. Clean. Prod. 2006, 14, 1480-1494. [CrossRef]

62. Ng, I.C.; Vargo, S.L. Service-dominant (SD) logic, service ecosystems and institutions: Bridging theory and practice. J. Serv. Manag. 2018, 29, 518-520. [CrossRef]

63. Anderl, E.; Becker, I.; Von Wangenheim, F.; Schumann, J.H. Mapping the customer journey: Lessons learned from graph-based online attribution modeling. Int. J. Res. Mark. 2016, 33, 457-474. [CrossRef]

64. Nam, S.; Ha, C.; Lee, H. Redesigning In-Flight Service with Service Blueprint Based on Text Analysis. Sustainability 2018, 10, 4492. [CrossRef]

65. Yang, L.; Xing, K.; Ness, D. A TRIZ-based multi-route model for product-service system design innovation. J. Des. Res. 2016, 14, 326-367. [CrossRef]

66. Kim, S.; Yoon, B. Developing a process of concept generation for new product-service systems: A QFD and TRIZ-based approach. Serv. Bus. 2012, 6, 323-348. [CrossRef]

67. Costa, N.; Patrício, L.; Morelli, N.; Magee, C.L. Bringing service design to manufacturing companies: Integrating PSS and service design approaches. Des. Stud. 2018, 55, 112-145. [CrossRef]

68. Qu, M.; Yu, S.; Chen, D.; Chu, J.; Tian, B. State-of-the-art of design, evaluation, and operation methodologies in product service systems. Comput. Ind. 2016, 77, 1-14. [CrossRef]

69. Vasantha, G.V.A.; Roy, R.; Lelah, A.; Brissaud, D. A review of product-service systems design methodologies. J. Eng. Des. 2012, 23, 635-659. [CrossRef]

70. National Institute for Standards and Technology (NIST). Standard for Integration Definition for Function Modeling (IDEF0); No. 183; Federal Information Processing Standards Publications: Springfield, MO, USA, 1993.

71. Macchi, M.; Fumagalli, L.; Garetti, M.; Tavola, G.; Checcozzo, R.; Rusinà, F.; Vidales Ramos, A.; Jokinen, J.; Popescu, C.; Martinez Lastra, J.L.; et al. Use case analysis method for the implementation of service-oriented solutions for monitoring and diagnostics. In Proceedings of the 24th International Congress on Condition Monitoring and Diagnostics Engineering Management COMADEM, Stavanger, Norway, 30 May-1 June 2011; pp. 406-413. 
72. Wu, X.; Chen, J.; Li, R.; Sun, W.; Zhang, G.; Li, F. Modeling a web-based remote monitoring and fault diagnosis system with UML and component technology. J. Intell. Inf. Syst. 2006, 27, 5-19. [CrossRef]

73. Sinkkonen, T.; Kivimäki, H.; Marttonen-Arola, S.; Galar, D.; Villarejo, R.; Kärri, T. Using the life-cycle model with value thinking for managing an industrial maintenance network. Int. J. Ind. Syst. Eng. 2016, 23, 19-35. [CrossRef]

74. Ukko, J.; Pekkola, S.; Saunila, M.; Rantala, T. Performance measurement approach to show the value for the customer in an industrial service network. Int. J. Bus. Perform. Manag. 2015, 16, 214-229. [CrossRef]

75. EN 17007. Maintenance Process and Associated Indicators; BSI: London, UK, 2017.

76. EN 15341. Maintenance. Maintenance Key Performance Indicators; BSI: London, UK, 2007.

77. Johnson, S.P.; Menor, L.J.; Roth, A.V.; Chase, R.B. A critical evaluation of the new service development process. In New Service Development: Creating Memorable Experiences; SAGE Publications Inc.: New York, NY, USA, 2000; pp. 1-32.

78. Aurich, J.C.; Mannweiler, C.; Schweitzer, E. How to design and offer services successfully. CIRP J. Manuf. Sci. Technol. 2010, 2, 136-143. [CrossRef]

79. Lee, S.H.; Xing, K.; Yang, L. Framework for PSS from service, perspective. In Proceedings of the International Multi Conference of Engineers and Computer Scientists, Hong Kong, China, 17-19 March 2010. Vol III IMECS.

80. Zhu, H.; Gao, J.; Li, D.; Tang, D. A Web-based Product Service System for aerospace maintenance, repair and overhaul services. Comput. Ind. 2012, 63, 338-348. [CrossRef]

81. Guo, L.; $\mathrm{Ng}$, I. The co-production of equipment-based services: An interpersonal approach. Eur. Manag. J. 2011, 29, 43-50. [CrossRef]

82. Nullmeier, F.M.; Wynstra, F.; van Raaij, E.M. Outcome attributability in performance-based contracting: Roles and activities of the buying organization. Ind. Mark. Manag. 2016, 59, 25-36. [CrossRef]

83. Kreye, M.E. Interactions between perceived uncertainty types in service dyads. Ind. Mark. Manag. 2018, 75, 90-99. [CrossRef]

84. Biege, S.; Lay, G.; Buschak, D. Mapping service processes in manufacturing companies: Industrial service blueprinting. Int. J. Oper. Prod. Manag. 2012, 32, 932-957. [CrossRef]

85. Crespo Márquez, A. The Maintenance Management Framework: Models and Methods for Complex Systems Maintenance; Springer Science \& Business Media: Berlin, Germany, 2007.

86. Tan, A.R.; Matzen, D.; McAloone, T.C.; Evans, S. Strategies for designing and developing services for manufacturing firms. CIRP J. Manuf. Sci. Technol. 2010, 3, 90-97. [CrossRef]

87. Saaty, R.W. The analytic hierarchy process-what it is and how it is used. Math. Model. 1987, 9, $161-176$. [CrossRef]

88. Macchi, M.; Crespo Márquez, A.; Holgado, M.; Fumagalli, L.; Barberá Martínez, L. Value-driven engineering of E-maintenance platforms. J. Manuf. Technol. Manag. 2014, 25, 568-598. [CrossRef]

89. Goffin, K.; New, C. Customer support and new product development-An exploratory study. Int. J. Oper. Prod. Manag. 2001, 21, 275-301. [CrossRef]

90. Essig, M.; Glas, A.H.; Selviaridis, K.; Roehrich, J.K. Performance-based contracting in business markets. Ind. Mark. Manag. 2016, 59, 5-11. [CrossRef]

91. Shih, L.H.; Lee, Y.T.; Huarng, F. Creating customer value for product service systems by incorporating internet of things technology. Sustainability 2016, 8, 1217. [CrossRef]

92. Grubic, T. Remote monitoring technology and servitization: Exploring the relationship. Comput. Ind. 2018, 100, 148-158. [CrossRef]

93. Antosz, K.; Stadnicka, D. Possibilities of Maintenance Service Process Analyses and Improvement Through Six Sigma, Lean and Industry 4.0 Implementation. In IFIP International Conference on Product Lifecycle Management; Springer: Cham, Switzerland, 2018; pp. 465-475.

(C) 2019 by the author. Licensee MDPI, Basel, Switzerland. This article is an open access article distributed under the terms and conditions of the Creative Commons Attribution (CC BY) license (http://creativecommons.org/licenses/by/4.0/). 